\title{
UPAYA PENGEMBANGAN POTENSI DESA MELALUI PENANGGULANGAN RISIKO BENCANA DI DESA BALAYO DAN DESA DUDEPO KECAMATAN PATILANGGIO KABUPATEN POHUWATO
}

\author{
Irawati Igirisa ${ }^{1}$, Rustam Tohopi ${ }^{2}$, Fenti Prihatini Tui ${ }^{3}$, Juriko Abdussamad ${ }^{4}$ \\ Universitas Negeri Gorontalo \\ irawatyigirisa17@ung.ac.id ${ }^{1}, \underline{\text { rustam@ung.ac.id }}{ }^{2}$, fentiprihatini@ung.ac.id $^{3}$, \\ jurikoabdussamad@yahoo.co.id ${ }^{4}$
}

\begin{abstract}
ABSTRAK
Tujuan Program KKS Pengabdian ini adalah untuk mendorong dalam upaya mengurangi risiko bencana melalui pengembangan potensi desa di desa Balayo dan desa Dudepo Kecamatan Patilanggio Kabupaten Pohuwato.

Kegiatan KKS Pengabdian melibatkan 30 orang Mahasiswa Peserta KKS yang disebarkan pada di Desa Balayo dan Desa Dudepo Kecamatan Patilanggio. Metode yang digunakan adalah melalui Pemberdayaan masyarakat dengan melakukan Pendidikan dan Pelatihan serta Pendampingan oleh Dosen Pembimbing Lapangan, dinas terkait dan mahasiswa peserta KKS yang ditempatkan dilokasi pengabdian. Pada tahapan awal tim bersama mahasiswa peserta KKS Pengabdian mengadakan observasi dan identifikasi terhadap permasalahan yang dihadapi oleh masyarakat, permasalahan yang terkait dengan pengembangan potensi desa dan aktivitas masyarakat serta pemerintahan desa akan dijadikan acuan pula dalam menyusun program kerja KKS Pengabdian.

Hasil dari kegiatan yang telah dicapai antara lain pembahasan rencana penanggulangan bencana, pembentukan forum relawan dan relawan penanggulangan bencana, pembuatan peta dan analisis resiko rawan bencana, pembuatan papan peringatan rawan bencana, pengembangan potensi desa yang dimiliki oleh desa yang dapat meningkatkan pendapatan masyarakat, penyuluhan kesehatan dan pemeliharaan kebersihan lingkungan dan pelatihan kripik pisang untuk peningkatan ekonomi dan kesejahteraan masyarakat desa.

Target akhir dari Program KKS Pengabdian ini menyiapkan desa tangguh bencana melalui peran forum relawan dan Satgas tangguh bencana di Desa Balayo dan Dudepo Kecamatan Patilanggio.
\end{abstract}

\section{Kata Kunci: Tangguh Bencana, Desa Mandiri}

\section{PENDAHULUAN}

Program pembangunan yang dilaksanakan di Kabupaten Pohuwato mengarah pada pengembangan potensi ekonomi yang dimiliki oleh masyarakat. Pada setiap kecamatan memiliki program unggulan yang berbeda-beda sesuai dengan potensi dan komoditas yang diunggulkan oleh kecamatan, seperti perikanan, coklat, kelapa, pertanian, industri, dan bidang lainnya. Untuk Kecamatan Paguat itu sendiri lebih dikenal dengan Kawasan Industri karena menjadi fokus pengembangan

Irawati Igirisa, Rustam Tohopi, Fenti Prihatini Tui, Juriko Abdussamad, 
industri di Kabupaten Pohuwato. Hal ini ditunjukkan dengan keberadaan beberapa industri dan ketersediaan sarana/prasarana penunjang industri yang sudah beroperasi di Paguat seperti Pelabuhan Laut dan pabrik minyak kelapa.

Dari hasil observasi awal ternyata upaya penanggulangan dan pengurangan risiko bencana serta pengembangan potensi ekonomi masyarakat yang ada di Desa Balayo dan Desa Dudepo. BUMDes di Kecamatan Patilanggio telah berdiri selama beberapa tahun terakhir ini dan mampu menunjang pengembangan UKM dan potensi desa. Keberadaan beberapa UKM yang mengolah hasil pertanian di Desa Balayo dan Desa Dudepo masih perlu sinkron dengan program BUMDes yang diharapkan menjadi wadah untuk mengembangkan seluruh potensi yang dimiliki oleh masyarakat.

Perkembangannya BUMDes masih perlu mendapatkan perhatian serius dari pihak Pemerintah Desa dan instansi yang terkait. Pengelolaan administrasi dan manajemen BUMDes masih perlu diperbaiki sehingga diharapkan seluruh potensi yang dimiliki oleh Desa Balayo dan Desa Dudepo dapat dikembangkan dengan baik. Di samping itu pula, UKM pengolah hasil pertanian dan perikanan perlu dibina, baik dari segi manajemen usahanya, ketrampilan dan teknik pengolahan hasil maupun dari segi pemasarannya.

Beberapa permasalahan pada pengelolaan BUMDes yang telah diidentifikasi dan dapat ditunjang dengan kegiatan KKS Pengabdian di
Desa Balayo dan Desa Dudepo antara lain adalah:

1. Terdapat UKM yang ada di Desa belum dapat melaksanakan kegiatan produksi secara baik.

2. Kontinuitas usaha yang dijalankan oleh UKM di Desa belum ada. Masyarakat hanya sewaktu-waktu melakukan kegiatan produksi baik pengolahan hasil pertanian.

3. UKM pengolahan hasil pertanian perlu di tata dan dibina sehingga mampu meningkatkan ketrampilan dan teknik produksi pengolahan, pengemasan dan pemasaran hasil produk dari UKM di Desa.

4. BUMDes belum mampu menjadi wadah organisasi yang dapat membantu pengembangan semua kegiatan UKM dan potensi yang dimiliki oleh masyarakat di Desa.

\section{Usulan Penyelesaian Masalah}

Untuk menyelesaikan beberapa permasalahan di Desa Balayo dan Desa Dudepo Kecamatan Patilanggio di atas, maka akan dilakukan kegiatan pemberdayaan bersama mahasiswa peserta KKS Pengabdian Destana dan masyarakat di lokasi pengabdian. Kegiatan yang akan dilakukan antara lain:

a. Sosialisasi dan simulasi bencana.

b. Pembentukan forum relawan dan tim relawan di kedua desa

c. Pembuatan Surat Keputusan Pengurus forum relawan dan tim relawan di kedua desa dan pelatikan pengurus.

d. Pembuatan Peta dan analisis risiko bencana

e. Pembuatan papan informasi publik tentang sistem peringatan dini bencana 
f. Ketahanan pangan untuk mengembangkan UKM yang ada di Desa Balayo dan Desa Dudepo maka akan dilakukan pelatihan dan pendampingan kepada UKM dengan melibatkan dinas terkait. Di samping itu, tim bersama-sama dengan mahasiswa peserta KKS Pengabdian akan melakukan pemberdayaan kepada masyarakat melalui usaha yang dilakukan oleh UKM, sehingga UKM dapat berproduksi dengan lebih baik lagi.

g. UKM yang ada didorong dan didampingi sehingga diharapkan usaha yang dijalankan oleh UKM akan berkontinuitas atau berlangsung secara terus menerus. Dalam hal ini akan dilakukan pendampingan dan pemberdayaan kepada UKM sehingga proses produksi akan semakin baik, ada diversifikasi produk hasil olahan pertanian yang dihasilkan oleh UKM sehingga pendapatan masyarakat semakin meningkat.

h. BUMDes belum mampu menjadi wadah organisasi yang dapat membantu mengembangkan semua kegiatan dan potensi yang dimiliki oleh masyarakat di Desa Balayo dan Desa Dudepo. Masih ada UKM yang tidak termasuk sebagai unit usaha yang dikelola oleh BUMDes. Dalam hal ini akan dilakukan pendampingan dan pemberdayaan UKM agar mau bergabung dalam wadah BUMDes.

\section{Teknologi/Metode Yang Digunakan Untuk Mengatasi Masalah}

Untuk mengatasi masalah yang dihadapi oleh mitra maka akan dilakukan penguatan melalui pembentukan forum relawan dan tim relawan di kedua desa; sosialisasi dan simulasi bencana; Pembuatan Surat Keputusan Pengurus forum relawan dan tim relawan serta pelatikan pengurus di kedua desa; Pembuatan Peta dan analisis risiko bencana; Pembuatan papan informasi publik tentang sistem peringatan dini bencana; dan penguatan ketahanan pangan untuk mengembangkan UKM yang ada di Desa Balayo dan Desa Dudepo melalui pelatihan dan pendampingan kepada UKM dengan melibatkan dinas terkait. Di samping itu, tim bersama-sama dengan mahasiswa peserta KKS Pengabdian akan melakukan pemberdayaan kepada masyarakat melalui usaha yang dilakukan oleh UKM, sehingga UKM dapat berproduksi dengan lebih baik lagi.

Lembaga mitra yang terlibat dalam kegiatan KKS Pengabdian Destana ini adalah pemerintah Desa Balayo dan Desa Dudepo bersama UKM dan masyarakat. Dalam hal ini akan dilakukan pada kedua desa yang ada, dimana kegiatan yang berkaitan penanggulangan bencana dilakukan koordinasi dengan dinas terkait dan kolaborasi mahasiswa KKS Pengabdian Destana. Khusus penguatan ketahanan ekonomi yaitu melalui pelatihan dan pemberdayaan akan dilakukan terintegrasi dengan kegiatan yang dilakukan oleh dinas terkait. Untuk pendampingan dan pemberdayaan akan dilakukan 
terhadap mitra dan mahasiswa KKS Pengabdian Destana sehingga setiap potensi yang dikembangkan dapat dipantau dan dievaluasi tingkat keberhasilannya.

Keseluruhan metode dan teknologi yang digunakan dalam kegiatan KKS Pengabdian Destana ini akan melibatkan ahli dan dosen pakar dari Universitas Negeri Gorontalo dan dinas terkait di Kabupaten Pohuwato dan seluruh mahasiswa peserta KKS Pengabdian Destana di lokasi pengabdian. Dengan demikian permasalahan yang dihadapi oleh mitra diharapkan dapat diselesaikan dengan baik, dan hasilkan akan mendorong peningkatan pendapatan masyarakat di Desa Balayo dan Desa Dudepo Kecamatan Patilanggio.

\section{Profil Kelompok Sasaran Dan Potensi / Permasalahan}

Desa Balayo dan Desa Dudepo Kecamatan Patilanggio Kabupaten Pohuwato masyarakatnya memiliki mata pencaharian yang beragam, seperti petani, peternak, pedagang, pegawai negeri, wiraswasta dan profesi lainnya.

Berdasarkan potensi yang dimiliki maka dalam kegiatan KKS Pengabdian Destana ini kedua desa ini memiliki potensi di bidang pertanian, pembinaan dan pemberdayaan terhadap mitra yaitu
UKM dan masyarakat yang melakukan pengolahan terhadap hasil pertanian dan perikanan. Dalam hal in akan ditetapkan 1 (satu) UKM yang mengolah hasil pertanian dan BUMDes yang ada di Desa Balayo dan Dudepo yang menjadi sasaran kegiatan yang akan dilakukan oleh tim pengabdi dan mahasiswa KKS Pengabdian Destana.

Untuk UKM pengolah ikan akan dilakukan pelatihan dan pendampingan tentang teknik pengolahan ikan menjadi berbagai diversifikasi hasil olahan seperti naget dan abon ikan. UKM akan ditata manajemen usahanya dan akan dilakukan perbaikan terhadap teknik produksi, pengemasan dan pemasaran hasil olahan ikan dari UKM di Desa Balayo dan Desa Dudepo Kecamatan Patilanggio. Sedangkan untuk pengembangan BUMDes akan dilakukan pelatihan dan pendampingan terhadap pengurus BUMDes terutama dalam pengelolaan administrasi dan keuangan BUMDes. Dalam pelaksanaan kegiatan akan diintegrasikan dengan kegiatan pemerintah desa dan RPJMDes (Rencana Program Jangka Menengah Desa) yang dilakukan dengan memanfaatkan ADD (Anggaran Dana Desa) yang dimiliki oleh Desa Balayo dan Desa Dudepo, seperti pada Tabel 1, berikut:

Tabel 1.1 Potensi Desa dan Permasalahannya

\begin{tabular}{|c|c|c|c|}
\hline $\mathrm{No}$ & $\begin{array}{c}\text { Nama } \\
\text { Desa }\end{array}$ & Potensi Desa & Hasil Observasi Mahasiswa \\
\hline \multirow[t]{2}{*}{1} & \multirow[t]{2}{*}{$\begin{array}{l}\text { Desa } \\
\text { Balayo }\end{array}$} & \multirow{2}{*}{$\begin{array}{l}\text { 1. Memiliki luas lahan } \\
\text { pertanian dan perkebunan } \\
\text { yang dapat dimanfaatkan }\end{array}$} & n yang sudah \\
\hline & & & Daerah \\
\hline
\end{tabular}

Irawati Igirisa, Rustam Tohopi, Fenti Prihatini Tui, Juriko Abdussamad, 


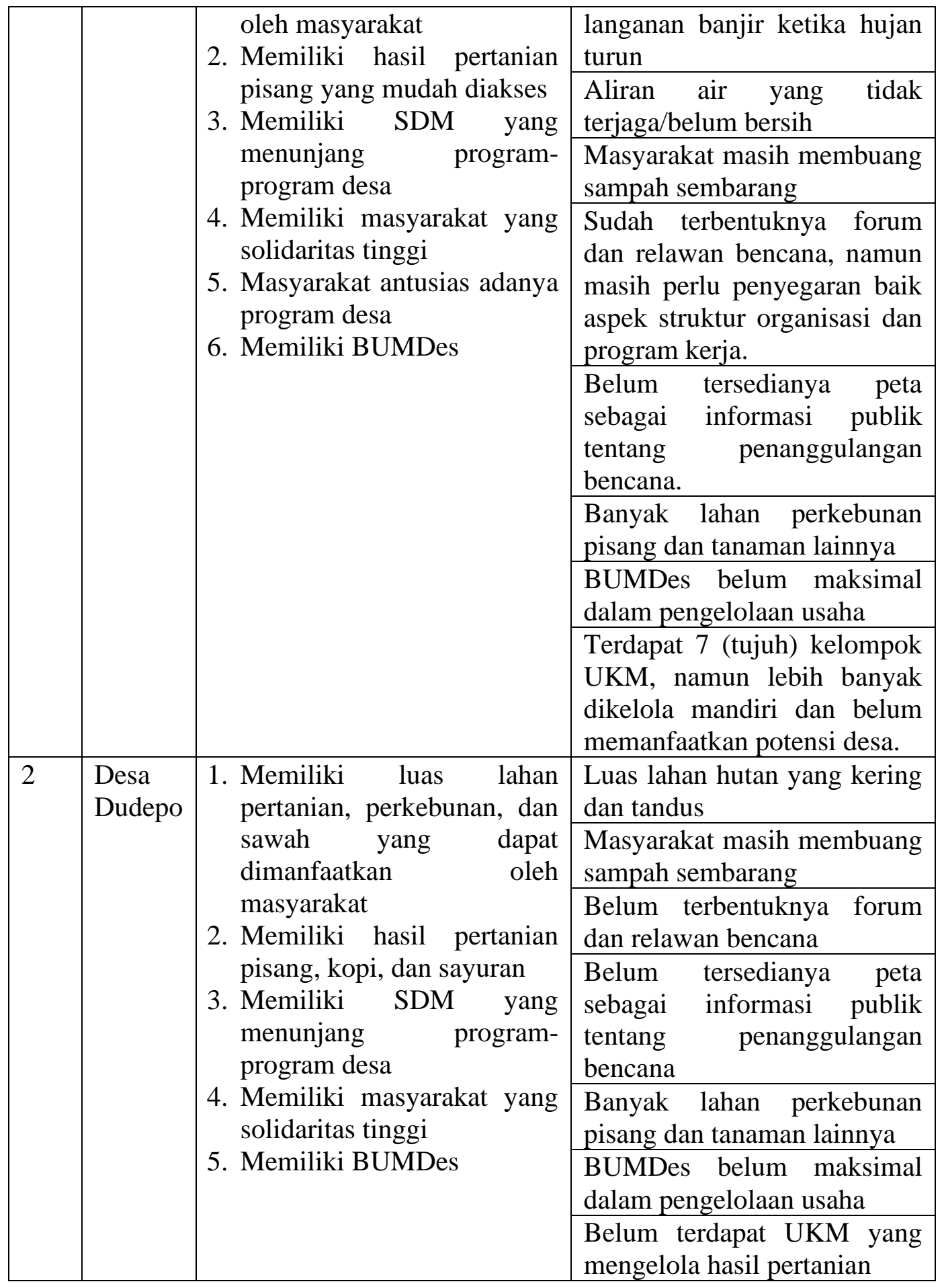

Sumber: Hasil Observasi Awal Tim DPL, 2018

\section{TARGET DAN LUARAN}

Target yang ingin dicapai dalam kegiatan KKS Pengabdian
Destana ini adalah mengacu dari permasalahan mitra, antara lain:

1. Terbentuknya forum relawan dan tim relawan Desa Balayo dan Desa Dudepo 
2. Tersosialisasinya Manajemen Bencana

3. Terbentuknya struktur pengurus forum relawan dan tim relawan Desa Balayo dan Desa Dudepo

4. Tersedianya informasi publik tentang Peta dan analisis resiko bencana

5. Berkembangnya

UKM pengolahan Kripik Pisang yang dilakukan melalui diklat manajemen usaha bagi UKM mitra, sehingga diharapkan usaha yang dijalankan oleh UKM di Desa Balayo dan Desa Dudepo semakin baik.

6. Terciptanya UKM yang mampu menjaga kontinuitas usaha dan proses produksinya dengan baik.

Target Luaran dari kegiatan KKS Pengabdian Destana ini, adalah mengacu dari permasalahan yang dihadapi oleh mitra, antara lain:

- Luaran wajib:

a. Artikel ilmiah yang dipublikasikan pada jurnal nasional atau prosiding nasional.

b. Publikasi pada media online repository UNG.

c. Pengembangan ketrampilan mitra/UKM pengolah Kripik Pisang sehingga dapat menghasilkan produk yang berkualitas.

d. Terbentuknya BUMDes yang dapat menampung semua potensi yang dimiliki oleh mitra dan dikelola secara profesional.

- Luaran tambahan:

a. Model penerapan teknologi pengolahan ikan dalam bentuk diversifikasi hasil olahan.
b. Pengembangan
BUMDes
sebagai model pengembangan ekonomi desa.
c. Publikasi ilmiah nasional (draf)

Tabel 1.2 Rencana Target Capaian Luaran

\begin{tabular}{|c|c|c|}
\hline No & Jenis luaran & $\begin{array}{l}\text { Indikator } \\
\text { capaian }\end{array}$ \\
\hline \multicolumn{3}{|c|}{ Luaran wajib: } \\
\hline 1. & $\begin{array}{l}\text { Publikasi } \\
\text { ilmiah pada } \\
\text { jurnal ISSN } \\
\text { atau prosiding }\end{array}$ & $\begin{array}{l}\text { Draf, } \\
\text { terdaftar }\end{array}$ \\
\hline 2. & $\begin{array}{l}\text { Peningkatan } \\
\text { ketrampilan } \\
\text { UKM dalam } \\
\text { membuat } \\
\text { diversifikasi } \\
\text { olahan kripik } \\
\text { pisang }\end{array}$ & $\begin{array}{l}\text { Sudah } \\
\text { dilaksanak } \\
\text { an }\end{array}$ \\
\hline 3. & $\begin{array}{l}\text { Terbentuknya } \\
\text { BUMDes yang } \\
\text { mampu } \\
\text { menampung } \\
\text { semua potensi } \\
\text { dan UKM }\end{array}$ & Penerapan \\
\hline \multicolumn{3}{|c|}{ Luaran tambahan: } \\
\hline 1. & $\begin{array}{l}\text { Model } \\
\text { penerapan } \\
\text { teknik } \\
\text { pengolahan } \\
\text { kripik pisang } \\
\end{array}$ & Penerapan \\
\hline 2. & $\begin{array}{l}\text { Model } \\
\text { BUMDes yang } \\
\text { mandiri dan } \\
\text { professional } \\
\text { sebagai wadah } \\
\text { yang dapat } \\
\text { mengembangk } \\
\text { an potensi } \\
\text { desa. }\end{array}$ & Penerapan \\
\hline 3. & $\begin{array}{l}\text { Publikasi } \\
\text { ilmiah nasional }\end{array}$ & Draf \\
\hline
\end{tabular}




\section{METODE PELAKSANAAN}

\section{Metode Penyelesaian Terhadap Permasalahan Mitra}

Untuk menyelesaikan permasalahan mitra dalam kegiatan KKS Pengabdian Destana ini akan dilakukan beberapa kegiatan. Dengan memperhatikan permasalahan yang dihadapi oleh mitra di atas, maka solusi yang ditawarkan antara lain:

a. Untuk menyelesaikan masalah terkait dengan pengurangan risiko bencana di Desa Balalyo dan Desa Dudepo dilakukan, pembentukan forum dan relawan bencana; pembuatan struktur organisasi, pembuatan peta rawan bencana di dua desa.

b. Kelompok UKM yang ada di Desa Balayo dan Dudepo maka akan dilakukan pelatihan dan pendampingan kepada UKM dengan melibatkan dinas terkait. Disamping itu, tim bersama-sama dengan mahasiswa peserta KKS Pengabdian Destana melakukan pemberdayaan kepada masyarakat melalui usaha yang dilakukan oleh UKM, sehingga UKM dapat berproduksi dengan lebih baik lagi.

c. Untuk menyelesaikan masalah kontinuitas usaha yang dijalankan oleh UKM maka diadakan pendampingan kepada UKM agar usaha yang dijalankan oleh UKM akan berkontinuitas atau berlangsung secara terus menerus. Dalam hal ini dilakukan pendampingan dan pemberdayaan kepada UKM sehingga proses produksi akan semakin baik, melalui diversifikasi produk hasil olahan kripik yang dihasilkan oleh UKM sehingga pendapatan masyarakat semakin meningkat.

d. Untuk menyelesaikan masalah BUMDes yang belum mampu menjadi wadah organisasi yang dapat membantu mengembangkan semua kegiatan dan potensi yang dimiliki oleh masyarakat di Desa Balayo dan Dudepo maka dilakukan pendampingan dan pemberdayaan UKM agar mau bergabung dalam wadah BUMDes.

\section{Persiapan Dan Pembekalan}

1. Mekanisme Pelaksanaan Kegiatan KKS Pengabdian

a) Mahasiswa yang telah direkomendasi oleh fakultas dan telah memenuhi syarat telah menyelesaikan minimal 115 SKS mendaftar secara online di laman lpm.ung.ac.id

b) Mahasiswa mengikuti seleksi dan pendaftaran sebagai calon peserta KKS Pengabdian yang diselenggarakan oleh LPPM UNG.

2. Materi persiapan dan pembekalan KKS Pengabdian yang perlu diberikan kepada mahasiswa antara lain:

a) Materi tentang teknis pelaksanaan KKS Pengabdian

b) Materi tentang kegiatan yang akan dilaksanakan oleh mahasiswa KKS Pengabdian sesuai dengan program yang telah ditentukan sebelumnya.

\section{PELAKSANAAN}

Untuk mencapai target dalam KKS Pengabdian Destana, maka 
dilaksanakan kegiatan pengabdian sesuai dengan program yang telah ditetapkan yaitu: pengurangan risiko bencana melalui pengembangan potensi Desa Balalyo dan Desa Dudepo, pengembangan BUMDes dan Diversifikasi Olahan hasil pertanian di Desa Balayo dan Desa Dudepo Kecamatan Patilanggio Kabupaten Pohuwato. Semua kegiatan yang dilaksanakan dikerjakan oleh tim dan mahasiswa peserta KKS Pengabdian Destana dan dinas terkait.

Pekerjaan yang dilaksanakan oleh mahasiswa dan dihitung dalam volume 144 Jam Kerja Efektif Mahasiswa (JKEM) dalam sebulan. Rata-rata JKEM per hari adalah 4.8 jam sebagai acuan. Uraian tabel dalam bentuk program dan jumlah mahasiswa pelaksana adalah:

Tabel 2. Uraian pekerjaan, Program dan Volume Jam Kerja Efektif Mahasiswa di Lokasi Pengabdian

\begin{tabular}{|c|c|c|c|c|}
\hline No & Nama Pekerjaan & Program & $\begin{array}{l}\text { Volume } \\
\text { (JKEM) }\end{array}$ & Keterangan \\
\hline 1 & $\begin{array}{l}\text { Pengembangan UKM pengolah } \\
\text { ikan }\end{array}$ & $\begin{array}{c}\text { Pelatihan, } \\
\text { pendampingan }\end{array}$ & 2016 & $\begin{array}{c}7 \text { orang } \\
\text { mahasiswa }\end{array}$ \\
\hline 2 & $\begin{array}{l}\text { Peningkatan ketrampilan UKM } \\
\text { (teknik pengolahan, } \\
\text { pengemasan dan pemasaran) }\end{array}$ & $\begin{array}{c}\text { Pelatihan, } \\
\text { pendampingan }\end{array}$ & 2304 & $\begin{array}{c}8 \text { orang } \\
\text { mahasiswa }\end{array}$ \\
\hline 3 & $\begin{array}{l}\text { Pengembangan } \\
\text { Usaha UKM dan } \\
\text { usaha }\end{array}$ & $\begin{array}{l}\text { Pelatihan dan } \\
\text { pendampingan }\end{array}$ & 2016 & $\begin{array}{l}7 \text { orang } \\
\text { mahasiswa }\end{array}$ \\
\hline 4 & $\begin{array}{l}\text { Pengelolaan BUMDes secara } \\
\text { professional } \\
\text { administrasi dan keuangan) }\end{array}$ & $\begin{array}{l}\text { Pendampingan } \\
\text { dan } \\
\text { Pemberdayaan }\end{array}$ & 2304 & $\begin{array}{l}8 \text { orang } \\
\text { mahasiswa }\end{array}$ \\
\hline \multicolumn{3}{|c|}{ Total Volume Kegiatan } & 8640 & $\begin{array}{l}30 \text { orang } \\
\text { mahasiswa }\end{array}$ \\
\hline
\end{tabular}

\section{Rencana Keberlanjutan Program}

Untuk Desa Tangguh Bencana dilakukan Kesiapsiagaan Bencana (pra, saat dan pasca) bencana; dan terbentuknya BUMDes yang mandiri dan mampu menampung dan mengembangkan UKM dan seluruh potensi yang dimiliki oleh mitra di dua Desa lokasi KKS Pengabdian Destana diharapkan dapat meningkatkan pendapatan masyarakat di Desa Balayo dan Desa Dudepo Kecamatan Patilanggio Kabupaten Pohuwato.

\section{Kelayakan Perguruan Tinggi}

a. Lembaga Penelitian dan Pengabdian pada Masyarakat (LPPM) Universitas Negeri Gorontalo (UNG) adalah merupakan lembaga yang memfasilitasi dosen dan mahasiswa dalam kegiatan pengabdian pada masyarakat. Untuk kegiatan mahasiswa ditujukan pada KKS dan KKN PPM yang merupakan salah satu syarat bagi mahasiswa dalam menyelesaikan program 
pendidikan Strata Satu (S1). Disamping itu, kegiatan dosen diarahkan pada kegiatan pengabdian yang mengutamakan kerjasama dengan instansi pemerintah dan mitra Perguruan Tinggi dan mitra (masyarakat) yang pembiayaannya melalui PNBP maupun dana DIPA Ditlitasmas Dirjen Kementrian Ristek Dikti. Dengan kegiatan Pengabdian Skim Program Kemitraan Masyarakat dilaksanakan oleh Tim Pengusul ini diharapkan dapat terjalin kerjasama yang baik antara UNG dengan instansi/lembaga pemerintah dan mitra (usaha) masyarakat, terutama dalam mendorong pertumbuhan ekonomi dan peningkatan pendapatan masyarakat. b. Dalam kegiatan pengabdian pada masyarakat KKS Pengabdian Destana ini diharapkan dapat ditransfer inovasi dan penerapan teknologi pengolahan ikan, pengembangan BUMDes secara professional yang dilakukan oleh dosen dan pakar yang terkait. Tim pengusul (Biodata dapat dilihat pada Lampiran 1) kegiatan ini adalah merupakan dosen dari perguruan tinggi pengusul yang terkait dengan aplikasi teknologi perikanan, pertanian yang secara langsung berdampak pada peningkatan pendapatan masyarakat dilokasi KKS Pengabdian Destana.

c. Struktur Organisasi Tim pengusul dan kemampuan (bidang ilmu)

Tabel 3. Struktur organisasi Tim Pelaksana Pengabdian KKS Pengabdian

\begin{tabular}{|c|l|c|c|}
\hline No & \multicolumn{1}{|c|}{ Nama } & Bidang ilmu & Bidang yang dikerjakan \\
\hline 1. & $\begin{array}{l}\text { Rustam Tohopi, S.Pd, } \\
\text { M.Si }\end{array}$ & $\begin{array}{c}\text { Administrasi } \\
\text { Publik / } \\
\text { Manajemen }\end{array}$ & $\begin{array}{c}\text { Memanej seluruh } \\
\text { kegiatan dan melakukan } \\
\text { pelatihan, } \\
\text { pendampingan dan } \\
\text { pemberdayaan mitra }\end{array}$ \\
\hline 2. & $\begin{array}{l}\text { Dr. Irawati Igirisa, } \\
\text { S.Pd.,M.Si }\end{array}$ & $\begin{array}{c}\text { Administrasi } \\
\text { Publik / } \\
\text { Manajemen }\end{array}$ & $\begin{array}{c}\text { Melakukan pelatihan } \\
\text { dan pendampingan dan } \\
\text { pemberdayaan mitra }\end{array}$ \\
\hline 3. & $\begin{array}{l}\text { Dr. Fenti Prihatini } \\
\text { Tui, S.Pd.,M.Si }\end{array}$ & $\begin{array}{c}\text { Administrasi } \\
\text { Publik / } \\
\text { Manajemen }\end{array}$ & $\begin{array}{c}\text { Melakukan pelatihan } \\
\text { dan pendampingan dan } \\
\text { pemberdayaan mitra }\end{array}$ \\
\hline 4 & $\begin{array}{l}\text { Dr Juriko } \\
\text { Abdussamad, MSi }\end{array}$ & $\begin{array}{c}\text { Administrasi } \\
\text { Publik }\end{array}$ & $\begin{array}{c}\text { Melakukan pelatihan } \\
\text { dan pendampingan } \\
\text { pemberdayaan mitra }\end{array}$ \\
\hline
\end{tabular}




\section{Hasil Dan Luaran Yang Dicapai}

Berdasarkan keputusan dari LPPM UNG lokasi KKS Pengabdian Destana Gelombang III Tahun 2018 dengan judul "Upaya Mengurangi Risiko Bencana Melalui Pengembangan Potensi Desa di Desa Balayo dan Desa Dudepo Kecamatan Patilanggio Kabupaten Pohuwato". Setelah melaksanakan kegiatan KKS Pengabdian Destana sejak tanggal 15 Oktober sampai dengan penarikan pada tanggal 28 Nopember 2018, maka hasil dari kegiatan yang telah dicapai antara lain:

1. Pembahasan rencana penanggulangan bencana.

Kegiatan telah dilakukan dengan mengadakan sosialisasi dan rencana penanggulangan bencana yang akan dilakukan jika terjadi bencana. Sosialisasi diikuti oleh perwakilan dari masyarakat dan tokoh pemuda pada setiap dusun dengan melibatkan petugas teknis dari Badan Penanggulangan Bencana Kabupaten Pohuwato. Dari hasil sosialisasi ini maka dibentuk forum relawan dan satgas tangguh bencana yang akan melaksanakan tugas di Desa Balayo dan Dudepo.

2. Pembentukan forum dan relawan penanggulangan bencana, telah dilakukan sebagai tindak lanjut dari kegiatan sosialisasi penanggulangan bencana. Di kedua desa yang menjadi lokasi kegiatan KKS Forum dan Satgas tangguh bencana telah dibentuk dan dilantik oleh Pemerintah Desa dan dihadiri oleh Camat

3. Patilanggio serta petugas dari Dinas Penanggulangan Bencana
Kabupaten Pohuwato. Pembuatan peta dan analisis resiko rawan bencana. Peta dan analisis resiko rawan bencana telah dibuat dan dipasang di Kantor Desa Balayo dan Dudepo Kecamatan Patilanggio.

4. Pembuatan strutur organisasi forum relawan dan tim relawan di dua desa dan diinformasikan kepada publik (masyarakat) umum dalam bentuk SK Kepala Desa.

5. Pembuatan papan peringatan rawan bencana. Kegiatan telah dilaksanakan bekerjasama dengan forum relawan dan satgas tangguh bencana dikedua desa yang menjadi lokasi KKS.

6. Pengembangan potensi yang dimiliki oleh desa yang dapat meningkatkan pendapatan masyarakat. Kegiatan telah dilakukan dengan membuat pelatihan pembuatan kripik pisang

7. Pembahsan kegiatan pengembangan BUMDes di kedua desa.

8. Penyuluhan kesehatan dan pemeliharaan kebersihan lingkungan serta pengelolaan/pemanfatan Sumber Daya Alam. Kegiatan telah dilaksanakan dengan melibatkan masyarakat dilokasi KKS Pengabdian Destana dan generasi muda yang tergabung dalam forum relawan dan satgas tangguh bencana, melalui penanaman pohon sukun okulasi.

\section{PEMBAHASAN}

Merujuk pada Undang-Udang Nomor 23 Tahun 2014 tentang Pemerintah Desa dijelaskan bahwa 
Desa merupakan ujung tombak pelaksanaan pemerintah paling terdepan dalam sistem penyelenggaraan Pemerintahan Negara Indonesia. Lahirnya UU Nomor 23 tahun 2014 tentang Pemerintahan Daerah memberikan peluang bagi desa untuk mewujudkan otonomi desa.

Melihat kondisi di Desa Balayo dan Desa Dudepo Kecamatan Patilanggio Kabupaten Pohuwato, masyarakat di dua desa sekarang ini perlu masih perlu dukungan penuh dan atau perhatian pemerintah daerah dan pusat dalam perubahan posisi menjadi desa yang mandiri, agar desa ini lebih percaya diri dalam mengelola desanya.

Pembangunan desa bertujuan meningkatkan kesejahteraan masyarakat desa dan kualitas hidup manusia serta meningkatkan daya saing melalui pemahaman kebutuhan dasar, pembangunan sarana dan prasarana desa, pengembanagan ekonomi lokal serta pemanfataan sumberdaya alam dan lingkungan secara berkelanjutan dimana pembangunan desa meliputi tahapan perencanaan, pelaksanaan, dan pengawasan.

Pemenuhan pembangunan sarana dan prasarana desa dalam pengabdian ini dilakukan melalui penerapan teknologi tentang early warning system atau sistim peringatan dini dalam penanggulangan bencana. Hal ini dimaksudkan agar masyarakat dapat memahami simbol-simbol yang diberikan ketika terjadi bencana. Misalnya peta desa rawan bencana, struktur relawan desa dan sumber informasi lainnya.

\section{SIMPULAN}

Dari kegiatan KKS

Pengabdian Destana yang telah dilaksanakan di Desa Balayo dan Dudepo maka dapat ditarik kesimpulan:

a. Kegiatan KKS Pengabdian Destana adalah merupakan salah tema yang perlu dikembangkan dalam rangka menyiapkan masyarakat dalam menanggulangi bencana terutama melalui pembentuk forum relawan dan satgas tangguh bencana di setiap desa yang menjadi lokasi KKS Pengabdian.

b. Pembentukan forum relawan dan satgas tangguh bencana sangat diperlukan dalam menyiapkan masyarakat untuk menghadapi bencana.

c. Pembentuk UKM yang dapat membantu pengembangan potensi ekonomi desa sangat diperlukan dalam upaya peningkatan pendapatan masyarakat di lokasi KKS Pengabdian Destana.

\section{SARAN}

a. Untuk mengefektivkan Program KKS Pengabdian di masa mendatang perlu diadakan penyesuaian program-program oleh desa yang akan dilaksanakan menjadi lokasi KKS Pengabdian.

b. Monitoring terhadap pelaksanaan kegiatan KKS Pengabdian perlu dilakukan sebagai upaya untuk memperbaiki pelaksanaan KKS dimasa mendatang.

\section{DAFTAR PUSTAKA}

Kemenristek Dikti. 2018. Panduan Penelitian dan Pengabdian 
Pada Masyarakat LPPM UNG

Edisi 1

Gitosudarmo, Indrianyo. 2000.

Manajemen Pemasaran,

Yogyakarta : BPFE Universitas

Negeri Gorontalo. - Tor KKS

Pengabdian, PNBP UNG 2018 